\title{
Vowel Deletion and Insertion in Úwù
}

\author{
Idris Olawale Allison \\ Ekiti State University
}

\begin{abstract}
Correspondence concerning this article should be addressed to Idris Olawale Allison, Department of Linguistics and Nigerian Languages, Faculty of Arts, Ekiti State University, Iworoko road, Ado Ekiti, Ekiti State, Nigeria, 360213. E-mail: idrisallison2012@yahoo.com
\end{abstract}

\begin{abstract}
Úwù is one of the many endangered languages in Nigeria.The number of its fluent speakers is believed to be less than 2000 . The language is spoken in a small community known as Àyèré in İjùmú Local Government Area (LGA) of Kogi state. This paper describes the manifestation of vowel deletion and insertion in the language with the view of testing earlier assertions on the nature of vowel deletion and insertion in languages that are genetically related to Úwù. Apart from this, the paper is also an attempt to document these phonological phenomena (i.e. vowel deletion and insertion) before the language goes into extinction. About six hundred (600) lexical items of Úwù were collected for this research work with the aid of the 1000 word-list of the Summer Institute of Linguistics. Both linear and non-linear models were adopted for analysis in this research work. Cases involving segmental phonemes were analyzed with the linear phonology, while cases of feature stability and feature spread wereanalyzed using the non-linear model. The paper, among other things, reveals that the pattern of vowel deletion is predictable in Úwù, auto-segments like tone (mostly high tone), nasality and labial or round features usually persist even when the vowel which bore them was deleted. Apart from this, the paper also reveals that [i] is the epenthetic vowel in Úwù, and lastly, it is argued in the paper that nouns in Úwù are virtually vowel initial.
\end{abstract}

Keywords: Vowel deletion, Insertion, Linear Phonology, Autosegmental Phonology, Prothesis

Earlier scholarly works in the area of phonology have proven that vowel deletion and insertion are two of the most productive phonological processes observed in many languages of the world (Glowacka, 2001; Uffmann, 2002; Frajzyngier, 2003; Hall, 2006). Research works carried out on the phonology of many African languages and precisely Benue-Congo languages have shown that there is hardly any African language that does not manifest the two or at least one of these phonological processes. Scholars, including Elugbe (1973), Egbokhare (1990), and Abiodun (2000; 2004), have all shown the pattern of vowel deletion in, Edo, Emai, Ukaan, and Yorùbá languages. Elugbe (1973) and Egbokhare (1990), report that vowel deletion is unpredictable in Edo and Emai languages because sometimes the first vowel (henceforth $V_{1}$ ) is deleted and some other times the second vowel (henceforth $V_{2}$ ) could be deleted in a $\mathrm{V}_{1} \# \mathrm{~V}_{2}$ construction. According to Egbokhare (1990), the choice of the deleted vowel is determined by the morpho-syntactic relations between the lexical sequences bearing the vowels (in Emai). Abiodun (2000; 2004) also reports that vowel deletion is also unpredictable in both Ukaan and Yorùbá languages. According to him, on vowel deletion within a verb phrase in Yorùbá, the vowel of the verb is most likely deleted if the noun is a derived one. However, in the case of an underived noun, any of $\mathrm{V}_{1}$ or $\mathrm{V}_{2}$ could be deleted.

On the pattern of vowel insertion, earlier scholars who have worked on various Benue-Congo languages have shown that vowels are usually inserted to break unwanted consonant clusters in languages that do not manifest consonant clusters. Apart from this, vowels may also be inserted to ensure that a vowel 
ends every word in a language that operates only the open syllable type. Lastly, a vowel may also be inserted in the form of a prothesis so that a consonant-initial word conforms to the syllable structure of a language where non-verbal words are mainly vowel initial. A typical example of such a language is Edo as reported in Adeniyi (2008).

In this paper, these two phonological phenomena are described and by implication documented in the Úwù language. The paper is divided into four sections. Section one is the introduction, section two presents the pattern of vowel deletion in Úwù, while section three presents the pattern of vowel insertion in the language. Finally, section four is the conclusion of the paper.

\section{Materials and Methods}

\section{Vowel Deletion Úwù}

According to Abiodun (2007), the deletion process involves a loss of sound, which may be a vowel, a consonant, or a suprasegment. This paper shows that vowel deletion is very robust in the Úwù language. The process is technically referred to as elision. As the name implies, it is the loss of a vowel in the course of derivation. On the effect of vowel deletion in languages where it occurs, Bamgbose (2006, p. 56) comments that; "Such a loss (of vowel) leads to the reduction in the number of syllables in the word or phrase".

The process of elision in Úwù occurs in three different grammatical constructions that include:

i. associative morpheme + noun

ii. verb + noun

iii. pronoun + future tense morpheme

\section{Vowel Deletion in Associative Morpheme + Noun}

In Úwù, a noun-noun construction is usually mediated by a medial particlewhich prevents the occurrence of two nouns across word boundaries. Ibikunle (2014) observes a similar particle which performs the same function in İyínnọ́ (a dialect of Àíka spoken in Ondo state). Ibikunle (2014) referred to this particle as "associative morpheme" henceforth (AM). The same nomenclature is therefore adopted for the particle in this study. In Úwù, this study reveals that the associative morpheme is underlyingly "ni”. However, the vowel of the morpheme is usually deleted whenever thenoun after the word boundary in the construction begins with a vowel, but when the noun after the word boundary begins with a consonantthe vowel of the associative morpheme becomes overt. Consider the examples in 1 (a) and (b) below:

\begin{tabular}{|c|c|c|c|c|c|}
\hline \multirow[t]{7}{*}{ 1. (a) } & i. & $\begin{array}{l}\text { opĩnì àtá } \\
\text { water AM gushing }\end{array}$ & $\rightarrow$ & ojĩnằtá & 'spring' \\
\hline & ii. & $\begin{array}{l}\text { àdzánìajĩku } \\
\text { house AMfaeces }\end{array}$ & $\rightarrow$ & àdzánãjĩku & 'toilet' \\
\hline & iii. & $\begin{array}{l}\text { anũnìùa } \\
\text { mouth AMdoor }\end{array}$ & $\rightarrow$ & anũnuั̀wá & ‘door way’ \\
\hline & iv. & $\begin{array}{l}\text { ahi nì àdzá } \\
\text { stomach AM house }\end{array}$ & $\rightarrow$ & ahinằdzá & 'room' \\
\hline & v. & $\begin{array}{l}\text { Jkò nìćdzé nìojĩ } \\
\text { vehicle AM } \\
\text { eye AM water }\end{array}$ & $\rightarrow$ & 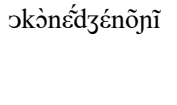 & 'boat/ship' \\
\hline & vi. & $\begin{array}{l}\text { okj̉ nì Adé } \\
\text { vehicle AM Ade }\end{array}$ & $\rightarrow$ & skכ̉nadé & 'Adé's car' \\
\hline & vii. & $\begin{array}{l}\text { عdza nì írì̀gòrĩgo } \\
\text { egg AM ant }\end{array}$ & $\rightarrow$ & edzanî́rì̀gòrĩgo & 'rice' \\
\hline \multirow[t]{4}{*}{ 1(b) } & i. & $\begin{array}{l}\text { opĩ ni kòǹga } \\
\text { water AM well }\end{array}$ & $\rightarrow$ & onĩnìkònga & 'well water' \\
\hline & ii. & $\begin{array}{l}\text { àkì nì Bólá } \\
\text { cloth AM Bólá }\end{array}$ & $\rightarrow$ & àkì nìbólá & $\begin{array}{l}\text { 'Bola's } \\
\text { cloth' }\end{array}$ \\
\hline & iii. & $\begin{array}{l}\text { ùwà enì tífà } \\
\text { food AM teacher }\end{array}$ & $\rightarrow$ & 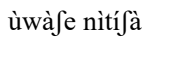 & $\begin{array}{l}\text { 'teacher's } \\
\text { food' }\end{array}$ \\
\hline & iv. & $\begin{array}{l}\text { àdzá nì taju } \\
\text { house AM Tayo }\end{array}$ & $\rightarrow$ & àdzá nìtájว̀ & $\begin{array}{l}\text { 'Tayo's } \\
\text { house' }\end{array}$ \\
\hline
\end{tabular}

As shown in 1 (a-b) above, the vowel of the associative morpheme which is contiguous with the first sound of the noun after the word boundary is lost at the derived form of the construction throughout the examples in 1 (a). This is because the initial sound of the noun after the word boundary is a vowel. However, the case in 1 (b) is different because the nouns after the word boundaries begin with consonants. This implies that for deletion to take place in an "associative morpheme + noun construction" in Úwù, the noun after the morpheme boundary must begin with a vowel. It is noted that the nasal feature of the alveolar nasal; [n] is usually acquired by the vowel [i] of the associative morpheme. It is also noted that the nasal feature is usually transferred to the initial vowel of the noun after vowel [i] is deleted. This shows that when the vowel is deleted, its nasal feature persists. The deletion rule is captured by the rule below:

2. $\left[\begin{array}{l}+ \text { syll } \\ + \text { high } \\ \text {-back }\end{array}\right] \longrightarrow \emptyset /-\#[+$ syll $]$

On the pattern of deletion in Úwù, it is observed that, the vowel [i] of the associative morpheme which is always the deleted segment shows that in an "associative morpheme + noun construction", $\mathrm{V}_{1}$ is usually deleted and its nasal feature transfers to $V_{2}$ in $a V_{1} \# V_{2}$ construction.

It should be recollected as said earlier that this phenomenon is not peculiar to Úwù alone as Ibikunle (2014) reports a similar case in Iyinno. The examples below show the manifestation of the associative morpheme in Iyinno: 


\section{VOWEL DELETION AND INSERTION IN ÚWÙ}

(Ibikunle, 2014, p. 13)

\begin{tabular}{|c|c|c|c|c|}
\hline a. & $\begin{array}{l}\text { èná mè àháĩ } \\
\text { meat AM farm }\end{array}$ & $\rightarrow$ & [عnómãháĩ] & 'animal' \\
\hline b. & $\begin{array}{l}\text { àfú mè itítí } \\
\text { faeces AM Titi }\end{array}$ & $\rightarrow$ & [àfúmĩtítí] & 'Titi's faecces' \\
\hline c. & $\begin{array}{l}\text { àfú mè ehú } \\
\text { faeces AM rat }\end{array}$ & $\rightarrow$ & [àfúmẽhú] & 'rice' \\
\hline
\end{tabular}

The examples from Iyinno have shown that just as the vowel [i] of the associative morpheme is deleted whenever the noun after the word boundary begins with a vowel in Úwù, the vowel $[\varepsilon]$ of the morpheme is also deleted in Iyinno whenever the noun after the word boundary begins with a vowel.

\section{Vowel Deletion in Verb + Noun}

Elision within a verb phrase is highly productive in Úwù. This is not strange as several scholars have shown that vowel deletion is highly productive in various languages of the worl. Scholars like Elugbe (1973), Egbokhare (1990), Schiffman (1993), Abiodun (2000; 2004), Molczanow (2007) among others have shown the robustness of vowel deletion within a verb phrase in different languages. Apart from the robustness of vowel deletion within a verb phrase, scholars in the area of phonology have also shown that the choice of the deleted vowel across word boundries in a $\mathrm{V}_{1} \#$ $\mathrm{V}_{2}$ construction varies from one language to another. While some languages delete $\mathrm{V}_{1}$ (e.g. Ukaan as shown in Abiodun (2000), other languages either delete $V_{1}$ or $\mathrm{V}_{2}$ (e.g. Yorùbá as shown in Awobuluyi (1978; 1988), Bamgbose (2006), and Abiodun (2004). For instance, the data below taken from Abiodun (2004, pp. 3-8) show that any of $V_{1}$ and $V_{2}$ could be deleted in a $V_{1}$ \# $\mathrm{V}_{2}$ construction in Yorùbá:

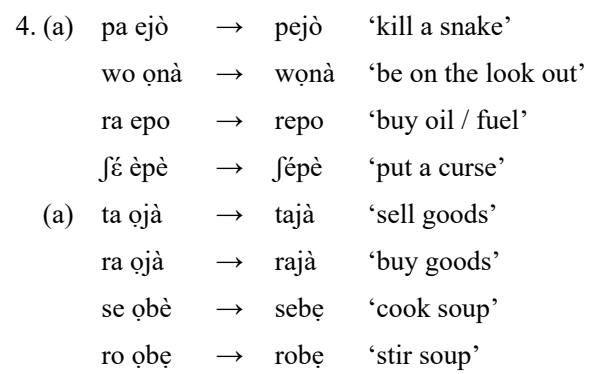

In the examples above, $\mathrm{V}_{2}$ survives deletion in 4 (a) while $V_{1}$ survives deletion in 4 (b). Based on the data presented above, it becomes convincing that the choice of the deleted vowel is unpredictable in Yorùbá.

This present study shows that vowel deletion within a verb phrase is highly productive in the Úwù language. Although, the phenomenon only occurs between a monosyllabic verb and a noun, in the case of a disyllabic or tri-syllabic verb, deletion does not occur, rather no phonological change is observed. But if the contiguous vowels are identical, then deletion will occur as the occurrence of identical vowels across the morpheme boundary is not allowed in Úwù. Consider the data below:

\begin{tabular}{|c|c|c|c|}
\hline \multirow[t]{8}{*}{ 5.(a) } & kwũfo غ̀ǹḑé & \multicolumn{2}{|c|}{ 'gather/ collect fruits' } \\
\hline & ruhi ólá & \multicolumn{2}{|l|}{ 'remember dream' } \\
\hline & fupá onwu & \multicolumn{2}{|l|}{ 'climb tree' } \\
\hline & lolı̀ ogo & \multicolumn{2}{|l|}{ ‘swim river’ } \\
\hline & bèrrè adż̀̀ & \multicolumn{2}{|l|}{ 'start work' } \\
\hline & Jueũ éwó & \multicolumn{2}{|l|}{ 'beat goat' } \\
\hline & fúéũ ómã & \multicolumn{2}{|l|}{ 'beat child' } \\
\hline & wúrèé olowù & \multicolumn{2}{|l|}{ 'ask for somebody' } \\
\hline (b) & gbala alè & $\rightarrow$ gbalalè & 'sweep floor’ \\
\hline & ruhi irĩ & $\rightarrow$ ruhirĩ & 'remember a song' \\
\hline & ruhi ilèmú & $\rightarrow$ ruhilèmú ‘ & 'remember an orange...' \\
\hline & kwũfo òwú & $\rightarrow$ kwũfòwú ' & gather/ collect threads' \\
\hline
\end{tabular}

As shown in data 5 ( $a$ and $b$ ) above, the items in 5 (a) do not reflect any phonological change, but those in 5 (b) reflect deletion. The difference is due to the kind of the contiguous segments as already said; those in 5 (b) are identical vowels, whereas those in 5 (a) are different vowels.

Apart from the above, the study also reveals that within a verb phrase where the verb before a noun is monosyllabic, in a $\mathrm{V}_{1} \# \mathrm{~V}_{2}$ construction in the language, it is always the $\mathrm{V}_{1}$ that gets deleted. The corpus data presented below validate our claim:

\begin{tabular}{|c|c|c|c|c|c|c|}
\hline i. & $\begin{array}{c}\int_{\mathrm{i}} \\
\text { take }\end{array}$ & + & $\begin{array}{c}\text { opĩ } \\
\text { water }\end{array}$ & $\rightarrow$ & 〔opĩ & $\begin{array}{l}\text { 'take } \\
\text { water' }\end{array}$ \\
\hline ii. & $\begin{array}{l}\int \mathrm{e} \\
\text { be }\end{array}$ & + & $\begin{array}{l}\text { oba } \\
\text { king }\end{array}$ & $\rightarrow$ & $\int \mathfrak{b a}$ & $\begin{array}{l}\text { 'become } \\
\text { king' }\end{array}$ \\
\hline iii. & $\begin{array}{l}\text { hí } \\
\text { cook }\end{array}$ & + & $\begin{array}{l}\text { ว̀̀dう̀ } \\
\text { soup }\end{array}$ & $\rightarrow$ & hốdò & 'cook soup' \\
\hline iv. & $\begin{array}{c}\text { jwi } \\
\text { give birth }\end{array}$ & + & $\begin{array}{l}\text { ómã } \\
\text { child }\end{array}$ & $\rightarrow$ & jóma & $\begin{array}{l}\text { 'give birth } \\
\text { to a child' }\end{array}$ \\
\hline v. & $\begin{array}{c}\text { fo } \\
\text { wash }\end{array}$ & + & $\begin{array}{l}\text { àki } \\
\text { cloth }\end{array}$ & $\rightarrow$ & fàkì & $\begin{array}{l}\text { 'wash } \\
\text { cloth' }\end{array}$ \\
\hline vi. & $\begin{array}{l}\text { kpu } \\
\text { kill }\end{array}$ & + & $\begin{array}{c}\text { Ena } \\
\text { animal }\end{array}$ & $\rightarrow$ & kpena & $\begin{array}{l}\text { 'kill (an) } \\
\text { animal' }\end{array}$ \\
\hline vii. & $\begin{array}{c}\text { ygo } \\
\text { weave }\end{array}$ & + & $\begin{array}{l}\text { àkì } \\
\text { cloth }\end{array}$ & $\rightarrow$ & ygàkì & $\begin{array}{l}\text { 'weave } \\
\text { cloth' }\end{array}$ \\
\hline viii. & $\begin{array}{l}\int e \\
\text { eat }\end{array}$ & + & $\begin{array}{l}\text { घ̀kpèjj } \\
\text { ground- } \\
\text { nut }\end{array}$ & $\rightarrow$ & 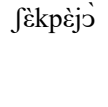 & $\begin{array}{c}\text { 'eat } \\
\text { groundnut' }\end{array}$ \\
\hline ix. & $\begin{array}{l}\text { dzí } \\
\text { steal }\end{array}$ & + & $\begin{array}{l}\text { ódzí } \\
\text { thief }\end{array}$ & $\rightarrow$ & dzódzí & $\begin{array}{c}\text { 'steal } \\
\text { something' }\end{array}$ \\
\hline $\mathrm{x}$. & $\begin{array}{l}\text { kó } \\
\text { learn }\end{array}$ & + & $\begin{array}{l}\text { ídsú } \\
\text { dance } \\
(\mathrm{N})\end{array}$ & $\rightarrow$ & kídzú & 'to dance' \\
\hline xi. & $\begin{array}{l}\text { kú } \\
\text { pack }\end{array}$ & + & $\begin{array}{l}\text { àkì } \\
\text { cloth }\end{array}$ & $\rightarrow$ & kwákì & $\begin{array}{l}\text { 'pack } \\
\text { clothes' }\end{array}$ \\
\hline xii. & $\begin{array}{l}\text { kú } \\
\text { pack }\end{array}$ & + & $\begin{array}{l}\text { àwù } \\
\text { shirt }\end{array}$ & $\rightarrow$ & kwáwù & $\begin{array}{l}\text { 'pack } \\
\text { shirts' }\end{array}$ \\
\hline
\end{tabular}




\begin{tabular}{|c|c|c|c|c|c|c|}
\hline xiii. & $\begin{array}{c}\text { gú } \\
\text { pound }\end{array}$ & + & $\begin{array}{c}\text { j̀dé } \\
\text { pounded } \\
\text { yam }\end{array}$ & $\rightarrow$ & 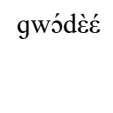 & $\begin{array}{c}\text { 'pound } \\
\text { pounded } \\
\text { yam' }\end{array}$ \\
\hline xiv. & $\begin{array}{l}\text { Se } \\
\text { do }\end{array}$ & + & $\begin{array}{l}\mathrm{i} \int \mathrm{l} l \mathrm{a} \\
\text { fight(N) }\end{array}$ & $\rightarrow$ & fifola & 'fight(V)' \\
\hline $\mathrm{xv}$. & $\begin{array}{c}\text { hथ } \\
\text { throw }\end{array}$ & + & $\begin{array}{l}\text { èkíta } \\
\text { stone }\end{array}$ & $\rightarrow$ & hềkíta & $\begin{array}{l}\text { 'throw } \\
\text { stone' }\end{array}$ \\
\hline xvi. & $\begin{array}{l}\text { jã } \\
\text { tear }\end{array}$ & + & $\begin{array}{c}\text { clé } \\
\text { money }\end{array}$ & $\rightarrow$ & jżદ́ & $\begin{array}{l}\text { 'tear } \\
\text { money' }\end{array}$ \\
\hline xvii. & $\begin{array}{c}\text { gbó } \\
\text { hear/listen }\end{array}$ & + & $\begin{array}{c}\text { irĩ } \\
\text { song }\end{array}$ & $\rightarrow$ & gbírĩ & $\begin{array}{l}\text { 'hear/ } \\
\text { listen to } \\
\text { song' }\end{array}$ \\
\hline xviii. & $\begin{array}{l}\text { jà } \\
\text { boil }\end{array}$ & + & $\begin{array}{l}\varepsilon d \text { cda } \\
\text { egg }\end{array}$ & $\rightarrow$ & jedza & 'boil egg' \\
\hline xix. & $\begin{array}{c}\text { gbé } \\
\text { abuse }\end{array}$ & + & $\begin{array}{l}\text { ’̀gá } \\
\text { boss }\end{array}$ & $\rightarrow$ & gbógá & $\begin{array}{l}\text { 'abuse/ } \\
\text { insult the } \\
\text { boss' }\end{array}$ \\
\hline $\mathrm{xx}$. & $\begin{array}{l}\text { dà } \\
\text { buy }\end{array}$ & + & $\begin{array}{l}\grave{\varepsilon} \int \hat{f}^{\prime} \\
\text { yam }\end{array}$ & $\rightarrow$ & $\mathrm{d} \hat{\varepsilon} \int \tilde{c}^{\prime}$ & 'buy yam' \\
\hline xxi. & $\begin{array}{l}\text { wù } \\
\text { wear }\end{array}$ & + & $\begin{array}{l}\text { àkì } \\
\text { cloth }\end{array}$ & $\rightarrow$ & wàkì & $\begin{array}{l}\text { 'wear } \\
\text { cloth' }\end{array}$ \\
\hline xxii. & $\begin{array}{c}\text { gù } \\
\text { demolish }\end{array}$ & + & $\begin{array}{c}\text { àdłá } \\
\text { house }\end{array}$ & $\rightarrow$ & gw àdzá & $\begin{array}{l}\text { 'demolish } \\
\text { house' }\end{array}$ \\
\hline xxiii. & $\begin{array}{c}\text { fu } \\
\text { untie }\end{array}$ & + & $\begin{array}{l}\text { éwó } \\
\text { goat }\end{array}$ & $\rightarrow$ & féwó & 'untie goat' \\
\hline xxiv. & $\begin{array}{c}\text { gbu } \\
\text { tie }\end{array}$ & + & $\begin{array}{l}\text { àkj̀ko } \\
\text { cock }\end{array}$ & $\rightarrow$ & gbàkj̀ko & 'tie cock' \\
\hline xxv. & $\begin{array}{l}\text { kpu } \\
\text { kill }\end{array}$ & + & $\begin{array}{l}\text { áfwá } \\
\text { dog }\end{array}$ & $\rightarrow$ & kpáfwá & 'kill dog' \\
\hline
\end{tabular}

From the examples above, it is apparent that the choice of the vowel that gets deleted is predictable; that is, only the vowels of the verbs are deleted. It is also evident in the data that the choice of vowels deleted is by no means dependent on the type of vowels of the verbs or nouns involved, or the form of the nouns (i.e. whether derived or underived); rather, it depends on the position of the vowel as it must be $\mathrm{V}_{1}$ which is the vowel of the verb. Another point that needs to be emphasized here is that the vowels are not usually deleted with all their features. We observe that, such autosegmental features like tone (specifically high tone) (e.g. iii), nasality (e.g. xv), and roundness features (e.g. xi) usually persist only to realign with other segments within their environments. This kind of behavior is referred to as feature stability within the autosegmental theory, and it has shown us the relevance of the theory to this work. The illustration below shows the pattern of deletion within a verb phrase in the language:

$[\mathrm{V}]_{1} \rightarrow \varnothing /-\#[\mathrm{~V}]_{2} \quad: \quad[+$ syll $] \rightarrow \emptyset /-\#[+$ syll $]$

It is also important that we discuss a type of phonological change that occurs between a verb and a consonant-initial noun as shown in the data below:

Note that the asterisked examples below are deviant.

\begin{tabular}{|c|c|c|c|c|c|c|}
\hline i. & $\begin{array}{l}\int \mathrm{e} \\
\text { eat }\end{array}$ & $\stackrel{+}{+}$ & dodo & $\rightarrow$ & Jidodo & 'fry plantain' \\
\hline ii. & $\begin{array}{l}\text { dà } \\
\text { buy }\end{array}$ & $\begin{array}{c}+ \\
\text { shoe }\end{array}$ & bata & $\rightarrow$ & dibata & 'buy shoe' \\
\hline iii. & $\begin{array}{l}\text { tà } \\
\text { sell }\end{array}$ & $\begin{array}{c}+ \\
\text { belt }\end{array}$ & bélíitì & $\rightarrow$ & tibélíitì & 'sell belt' \\
\hline iv. & $\begin{array}{l}\text { dá } \\
\text { go }\end{array}$ & $\begin{array}{c}+ \\
\text { school }\end{array}$ & súkúrù & $\rightarrow$ & dísúkúrù & 'go to school' \\
\hline v. & $\begin{array}{l}\text { wá } \\
\text { come }\end{array}$ & $\begin{array}{c}+ \\
\text { school }\end{array}$ & súkúrù & $\rightarrow$ & wísúkúrù & $\begin{array}{l}\text { 'come to } \\
\text { school' }\end{array}$ \\
\hline vi. & $\begin{array}{l}\text { wá } \\
\text { come }\end{array}$ & $\begin{array}{c}+ \\
\text { church }\end{array}$ & ઈ’่́̀ & $\rightarrow$ & 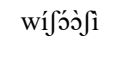 & $\begin{array}{l}\text { 'come to } \\
\text { church' }\end{array}$ \\
\hline vii. & $\begin{array}{c}\text { * bère } \\
\text { start }\end{array}$ & $\begin{array}{c}+ \\
\text { school }\end{array}$ & sùkúrù & $\rightarrow$ & $\begin{array}{l}\text { bèrrè } \\
\text { sùkúrù }\end{array}$ & $\begin{array}{c}\text { 'start } \\
\text { schooling' }\end{array}$ \\
\hline viii. & $\begin{array}{c}* \\
\text { wúrèé } \\
\text { ask }\end{array}$ & $\begin{array}{c}+ \\
\text { shoe }\end{array}$ & bàtà & $\rightarrow$ & $\begin{array}{l}\text { wúrèé } \\
\text { bàtà }\end{array}$ & $\begin{array}{l}\text { 'ask/request } \\
\text { for shoe' }\end{array}$ \\
\hline
\end{tabular}

From the data above, it is observed that a high front vowel [i] which is not present at the underlying representation surfaces at the phonetic representation. This change may make a casual observer to assume that the vowel of the verb changed to [i] whenever the noun begins with a consonant. However, this kind of assumption may not be correct because one may not be able to account for this kind of change as it is not a common phonological process that occurs in natural languages. Alternatively, one may assume that the vowels of the monosyllabic verbs were deleted and an extraneous vowel [i] introduced to block the cluster of consonants resulting from the deleted vowels. Consider the illustration below:

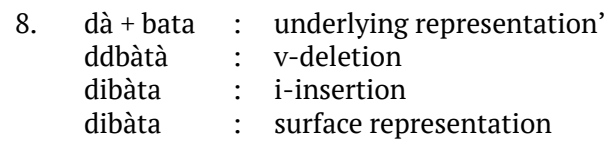

Although this assumption may appear to be more logical than the first one, it is worrisome to have the two rules; v-deletion and i-insertion to both apply to a single structure to arrive at its surface representation. One needs to ask the following questions:

i. Why would a language delete a vowel only to replace it with another one?

ii. How logical is the order of application of the two rules in terms of naturalness, economy, simplicity and plausibility?

The complexity and illogicality of the above rules may also compel one to consider a more appropriate and logical argument. This will lead one to assume that an extraneous vowel [i] which is technically referred to as a prothesis is introduced before the consonant initial-nouns so as to ensure that all nouns begin with a vowel in the language. The prothetic vowel [i] is covert when the nounsoccur as the subject of sentences as shown below:

Note that 9iii is deviant. 


\section{VOWEL DELETION AND INSERTION IN ÚWÙ}

9. i. sùkúrù ne Olu á dá
school foc. O prv go
ii. $\begin{aligned} & \text { bàtà ne Ade á dà } \\ & \text { shoe foc. A prv sold }\end{aligned}$$\quad \begin{aligned} & \text { 'it is school that Olu went' } \\ & \text { iii. "ishoe that Ade sold' } \\ & \text { school foc O prv go olu á dá }\end{aligned} \quad$ 'it is school that Olu went'

Meanwhile, the vowel is overt whenever the nouns occur before a monosyllabic verb. Based on this new hypothesis, the underlying forms of the data in (7) may now be re-presented as:

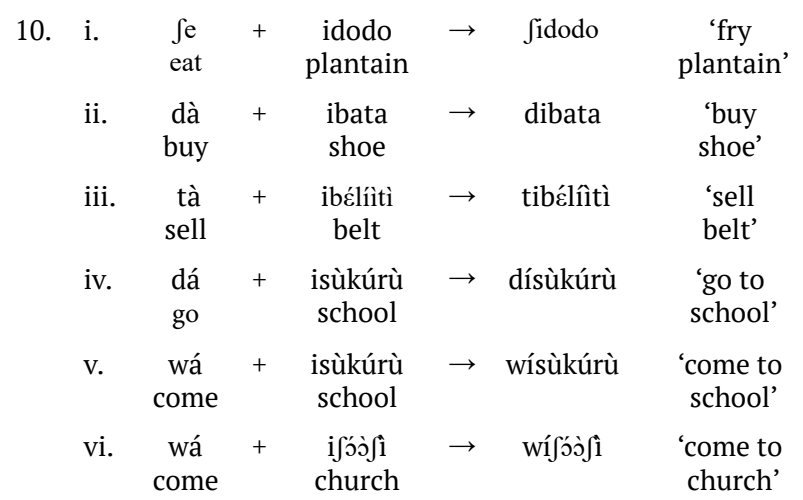

One salient observation about the data above is that all the nouns are borrowed words. It can also be deduced from the data that nouns in Úwù must begin with a vowel; this explains why all the nouns in (10) begin with vowel [i]. It can therefore be argued that vowel [i] is usually inserted at the beginning of a consonant-initial loanword so that such a word fits into the phonotactic structure of the Úwù language. This kind of insertion is not strange. Elugbe (1989) and Adeniyi (2008) have both demonstrated that all nouns (and all non-verbal words) in Edo are vowelinitial. As a result, when the language borrows a word that begins with a consonant, a prothetic vowel [e] or [i] is usually introduced to nativise such a word. According to Adeniyi (2008), the extraneous vowel is usually inserted at the beginning of every consonantinitial borrowed word so that the word conforms to the phonotactic rule of Edo. Whereas, the prothetic vowel in Úwù is [i], it is [e/i] in Edo. Consider the data below from Edo which were drawn from Adeniyi (2008, p. 65)

$\begin{array}{ll}\text { 11. èfiìmù } & \text { 'film' } \\ \text { èbélítì } & \text { 'belt' } \\ \text { èkóòmù } & \text { 'comb' } \\ \text { èkọ́rísà } & \text { 'chorister } \\ \text { ìbúrù } & \text { 'blue' } \\ \text { èbúrédì } & \text { 'bread' }\end{array}$

In the same vein, Awobuluyi (2013) argues that the vowel that exists between two nouns where the second one begins with a consonant in a Yorubá noun phrase like:

\section{2. ìwé e dàda 'Dada's book' \\ isu u kọ́lá 'Kola’s yam' \\ bàta a tísà 'Teacher's shoe' \\ ìlú u kánò 'the town of kano'}

is underlyingly [i] which is a prothetic vowel inserted at the beginning of a consonant-initial- noun as presented below:

$$
\begin{aligned}
& \text { 13. ìwé idada } \rightarrow \text { iwe e dada } \\
& \text { isu ikọla } \rightarrow \text { isu u kọla } \\
& \text { bata itísà } \rightarrow \text { bata a segun } \\
& \text { ìlú ikánò } \rightarrow \text { ilu u kano }
\end{aligned}
$$

The [i]-prothesis normally undergoes a perseverative assimilation such that it becomes like the final vowel of the first noun. He further asserts that all nouns in Yorùbá are vowel-initial. Oyebade (2008, p. 75 ) also reports a case of [e]-prothesis in Spanish. According to him, the language does not allow a consonant cluster that starts with the sibilant [s] to begin a word. When such happens, a vowel $[\varepsilon]$ is inserted at the beginning of the word:

$$
\begin{aligned}
& \text { 14. Espajol 'spanish' } \\
& \text { Eslavo 'slavic' } \\
& \text { esplin 'spleen' }
\end{aligned}
$$

The data presented in this section have also shown that just like the case of the 'associative marker + noun' $V_{1}$ is always the deleted vowel in a construction consisting of $\mathrm{V}_{1} \# \mathrm{~V}_{2}$ in the Uwù language.

\section{Results}

\section{Vowel Deletion in Pronoun + Future Tense

\begin{tabular}{|c|c|c|c|c|c|}
\hline \multirow[t]{5}{*}{ 15.(a) } & i. & $\begin{array}{l}\text { má égà dá } \\
\text { I FTM go }\end{array}$ & $\rightarrow$ & mégà dá & 'I will go' \\
\hline & ii. & $\begin{array}{l}\text { ygo égà dá } \\
\text { you FTM go }\end{array}$ & $\rightarrow$ & ygégà dá & 'you will go' \\
\hline & iii. & $\begin{array}{l}\text { wá égà dá } \\
\text { he/she TM go }\end{array}$ & $\rightarrow$ & wégà dá & $\begin{array}{l}\text { 'he/she will } \\
\text { go' }\end{array}$ \\
\hline & iv. & $\begin{array}{l}\text { awá égà dzídzú } \\
\text { we FTM dance }\end{array}$ & $\rightarrow$ & awégà ḋíçú & $\begin{array}{l}\text { 'we will dan- } \\
\text { ceo' }\end{array}$ \\
\hline & v. & $\begin{array}{l}\text { غ̀mé égà dzídzú } \\
\begin{array}{l}\text { you(pl) } \\
\text { dance }\end{array}\end{array}$ & $\rightarrow$ & غ̀mégà dzídzú & $\begin{array}{l}\text { 'you(pl) will } \\
\text { dance' }\end{array}$ \\
\hline
\end{tabular} Morpheme}

This study also reveals that vowel deletion normally occur between a pronoun and a future tense morpheme. The future tense morpheme (henceforth FTM) in Úwù is égà. Its manifestation is illustrated with the examples below; 


\begin{tabular}{|c|c|c|}
\hline vi. & $\begin{array}{l}\text { àmá égà dóíçu } \rightarrow \\
\text { they } \quad \text { FTM } \\
\text { dance' }\end{array}$ & 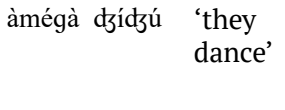 \\
\hline i. & $\begin{array}{l}\text { Adé égà dá } \\
\text { A FTM go }\end{array}$ & 'Ade will go' \\
\hline ii. & $\begin{array}{l}\text { Olú égà dá } \\
\text { O FTM go }\end{array}$ & 'Olu will go' \\
\hline iii. & $\begin{array}{ll}\text { wálé égà } & \text { dá } \\
\text { W FTM } & \text { go }\end{array}$ & 'Wale will go' \\
\hline iv. & $\begin{array}{l}\text { edzi égà dà } \\
\text { rain FTM fall }\end{array}$ & 'it will rain' \\
\hline v. & $\begin{array}{l}\text { mama égà dzi } \\
\text { thunder FTM strike }\end{array}$ & 'thunder will strike' \\
\hline vi. & $\begin{array}{l}\text { àdzá égà gu } \\
\text { house FTM collapse }\end{array}$ & 'the house will collapse' \\
\hline
\end{tabular}

In 15 (a) above, it is observed that the vowels of the pronouns get deleted before the FTM. However, in 15 (b) where the words before the FTM are nouns, the vowels of the nouns were not deleted. It appears therefore that Úwù language distinguishes between its nouns and pronouns by ensuring that the vowel of a pronoun is deleted before a FTM while that of a noun is not deleted in the same environment. It is also an indication that pronouns in Úwù may constitute clitics, since they have the ability to concatenate with the FTM which occurs after them. Radford et al (1999) describe such clitics as proclitics since they precede their hosts. This kind of concatenation between pronouns and verbs or preverbal particles is not strange. Radford et al (1999, p. 174) report that pronouns in Romance languages behave like proclitics while those of Spanish may behave like proclitics or enclitics depending on the form of the verb. The examples in 15 (a) above have also affirmed the earlier claim in this paper that $V_{1}$ is always deleted while $V_{2}$ survives in a $V_{1} \# V_{2}$ constructionin Úwù language. This implies that the pattern of deletion in Ûù is predictable. The illustration below shows the general pattern of deletion in the language.

$$
[+ \text { syll }] \rightarrow \emptyset /-\#[+ \text { syll }]
$$

\section{Discussion}

\section{Epenthesis in Úwù}

This is a process in which an extraneous segment (consonant or vowel) is introduced into a word to break up unacceptable sequences. It is also used to achieve the preferred syllable structure of a language. In Úwù,only vowels can be inserted into a word, consonant insertion does not exist in the language. Adeniyi (2008) reports that vowel insertion takes place in three positions in Edo. These are morpheme initial, medial and final. In Úwù, the same positions are also observed. According to Adeniyi (2008), the following forms can be pronounced in isolation in Edo (p. 65):

$\begin{array}{ll}\text { 16. èfiìmù } & \text { 'film' } \\ \text { èbélíì̀ } & \text { 'belt' } \\ \text { èkóòmù } & \text { 'comb' } \\ \text { èkórísà } & \text { 'chorister } \\ \text { ìbúrù } & \text { 'blue' } \\ \text { èbúrédì } & \text { 'bread' } \\ \text { However, in Úwù, they are realized as: } \\ \text { 17. fìmù } & \text { 'film' } \\ \text { bélíitì } & \text { 'belt' } \\ \text { kóòmù } & \text { 'comb' } \\ \text { kọ́rísítà } & \text { 'chorister } \\ \text { búlù } & \text { 'blue' } \\ \text { búrédì } & \text { 'bread' }\end{array}$

The same words are also assumed to be produced underlyingly as presented below when they are preceded by a verb:

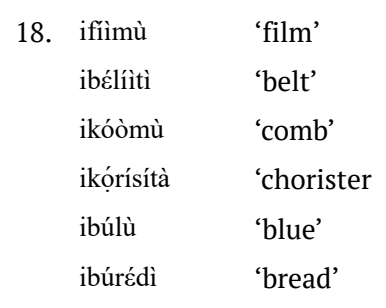

The realization of the prothetic vowel in Úwù has already been discussed in the previous section. In order to avoid repeating the same presentation; readers are advised to revisit section $\mathbf{2}$ for the argument on how the prothesis manifests in Úwù. Concerning the observation that the prothetic vowel [i] in Uwù only surfaces when a consonant initial-noun occurs after a verb, one can simply assume that the vowel is deleted when the nouns are in citation forms. The assumption that the vowel is deleted when the nouns are in citation forms appears to be correct because during an interaction with some native speakers of Úwù, it was observed that Úwù speakers do not normally distinguish between the forms of nouns in 19 and 20 below:

\begin{tabular}{|c|c|c|}
\hline 19. & ilógbò & 'rat' \\
\hline & ifola & 'fight (N)' \\
\hline & îjekpé & 'cane' \\
\hline & ìlèmú & 'orange' \\
\hline 20. & lógbò & 'rat' \\
\hline & fola & 'fight (N)' \\
\hline & $\int \varepsilon \mathrm{kp} \varepsilon \dot{ }$ & 'cane' \\
\hline & lèmú & 'orange' \\
\hline
\end{tabular}

The data above show that the presence or absence of vowel [i] in nouns that begin with the vowel does not distort meaning. It therefore appears that vowel [i] is commonly deleted optionally when it begins a noun 


\section{VOWEL DELETION AND INSERTION IN ÚWÙ}

in Úwù.This also points to the fact that Úwù nouns are probably vowel-initial and those nouns that are consonant-initial in the language are only products of clipping; it also seems like there is an on-going process of [i]-deletion at the initial position in Ûù nouns. It is also believed that the deletion of the vowel extends to consonant-initial borrowed words even when it was inserted to nativise such words. However, while the vowel is optionally deleted in the case of Úwù native words when they occur in isolation, it is obligatorily deleted in the case of borrowed words. The obligatory deletion of the vowel [i] at the beginning of a borrowed word when in isolation is believed to be influenced by the contact with Yorùbá language which is the lingua franca of the Àyèré people, or alternatively, those forms are rendered in Yorùbá, while the Úwù forms are already eroded. In Yorùbá, borrowed words are pronounced without the prothetic vowel [i] in citation form as presented below:

$\begin{array}{ll}\text { 21. bíbélì } & \text { 'bible' } \\ \text { tábílì } & \text { 'table' } \\ \text { fó̀jì } & \text { 'church' } \\ \text { súkúùlù } & \text { 'school' }\end{array}$

Inspite of the forms presented above, Awobuluyi (2008; 2013) has consistently argued thatall Yorùbá nouns are vowel-initial. He buttressed his claim by citing examples from the Mọ̀bà dialect where all consonant-initial nouns in Standard Yorùbá begin with vowel [i] in Mọbà. Consider the examples below:

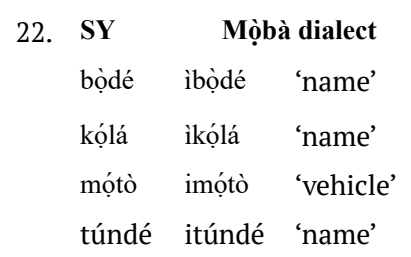

In view of the above argument by Awobuluyi, Ajiboye (2011) argues that the realization of the prothetic vowel [i] in Mọ́bà is context-based. According to Ajiboye, the prothetic vowel performs certain functions which include indicating possession and emphasis. However, when a supposed consonantinitial noun is pronounced in isolation, the prothetic vowels do not feature. This according to him explains why the following forms (Ajiboye, 2011, p. 58) are not acceptable forms in Mọbà and by extension in the Yorùbá language;

$$
\begin{aligned}
& \text { 23. * ìfilà } \\
& \text { * ikọ́kọ́ró } \\
& \text { * ìgèlè }
\end{aligned}
$$

Although the above forms may not be acceptable in citation, there are some other nouns in Yorùbá that begins with vowel [i]. Consider the examples below:

$$
\begin{array}{ll}
\text { 24. ilẹ̀kùn } & \text { 'door' } \\
\text { ìyàrá } & \text { 'room' } \\
\text { ìdòwú } & \text { 'name' } \\
\text { ìdògbé } & \text { 'name' } \\
\text { ìyẹ̀wù } & \text { 'room' } \\
\text { ìnàbì/ nàbì̀ } & \text { 'prostitution' }
\end{array}
$$

The nouns in (24) above and some others of the same form are believed to be the relics of the nouns that begin with the vowel [i] in Yorùbá. It therefore implies from a historical perspective that Yorùbá developed a rule that deletes the vowel [i] at word initial position in nouns, at some point along its historical development, and such words in (24) above and few others of the same form are the radical ones that were never affected by the deletion rule. Another area that supports the claim that [i] is often deleted in the Yorùbá language is the verb-noun construction. Awobuluyi (1988) and Abiodun (2004) both report that the pattern of deletion in Yorùbá may be predictable whenever [i] is involved. In the following examples, [i] is deleted as $\mathrm{V}_{1}$ and $\mathrm{V}_{2}$ :

$$
\begin{array}{ll}
\text { 25. dzí \# owó } \rightarrow \text { ḑówó } & \text { 'steal money' } \\
\text { ra \# ifu } \rightarrow \text { rafu } & \text { 'buy yam' }
\end{array}
$$

Ebira is another language just like Edo where nouns are mainly vowel-initial. Consonant-initial loanwords are also nativised in Ebira by inserting vowel [i] at

\begin{tabular}{|c|c|c|}
\hline English & \multicolumn{2}{|c|}{ Anaang } \\
\hline /waiə/ & àwaya & 'wire' \\
\hline /maygəu/ & amango & 'mango' \\
\hline /glæs/ & àglas & 'glass' \\
\hline /kəmpju:tə/ & àkomputa & 'computer' \\
\hline /fæn/ & afan & 'fan' \\
\hline
\end{tabular}
the beginning of such words. The examples below are drawn from Abiodun (2007):

\begin{tabular}{lll} 
26. & English & \multicolumn{2}{c}{ Ebira } \\
motəu & iməto & motor \\
bred & iburedi & bread \\
kəum & ikoomu & comb \\
sku:l & isukuru & school \\
pəlis & iporiisi & police
\end{tabular}

In the same vein, Anaang; a Benue-Congo language spoken in the Akwa Ibom state of Nigeria is another language whose nouns are mainly vowel-initial. When the language borrows a consonant-initial noun, [a]prothesis is inserted at the beginning of such a word so as to conform to the phonotactic structure of the language. Consider the examples below (Ekpe, 2012):

Evidence from Edo, Úwù, Yorùbá, Ebira and Anaang 


\section{IDRIS OLAWALE ALLISON}

languages presented above shows that nouns of most Benue-Congo languages are mainly vowel-initial, and various languages employ different prothesis to nativise loan words that are consonant-initial. For instance; it is [e/i] in Edo, it is also [i] in Úwù, Yorùbá and Ebira, whereas in Anaang it is [a]. From the foregoing, it becomes quite convincing that the prothetic vowel [i] is prespecified in the Úwù lexicon but it may be deleted when the nouns are in citation forms. However, the difference between Úwù and Yorùbá, and Edo, Ebira and Anaang is that while the prothetic vowels are deleted when the nouns are pronounced in isolation in the former, they are never deleted in the case of the latter.

Oyebade (1998, p. 75) reports that epenthesis is a very common phenomenon in the loan-word phonology of many African languages. The case of Úwù affirms this report as shown in the examples below:

\begin{tabular}{|c|c|c|c|}
\hline 28. & English & & \\
\hline & /belt/ & /belíitì/ & 'belt' \\
\hline & $/ \operatorname{br} \Lambda \rho /$ & /búróว̀jî/ & 'brush' \\
\hline & /breik/ & /búréèkí/ & 'brake' \\
\hline & /sku:1/ & /súkúrù/ & 'school' \\
\hline & /sleit/ & /síléètì/ & 'slate' \\
\hline & /kəum/ & /kóòmù/ & 'comb’ \\
\hline & /freim/ & /fúrémù/ & 'frame' \\
\hline & /bred/ & /búrédì/ & 'bread' \\
\hline & /treila/ & /tírélà/ & trailer' \\
\hline & /teibl/ & /tébù/ & 'table' \\
\hline
\end{tabular}

From the examples above, one notices that the sound [l] in /sku:l/ is realized as [r]; /súkúru/ 'school' in Úwù, whereas the sounds do not alternate in other words. The question posed by this irregular alternation is "how come it is only restricted to /sku:l/?" Two logical answers could be provided for this question; the first one is to suggest that the form must have been influenced by contact with Owé dialect of Yorùbá spoken in Kàbbà which is about 8 kilometers from Ayèré. Findings reveal that school is also pronounced as sùkúrù in Owé. This assumption is possible due to the close relationship that exists between the people of Àyèré and Kàbbà. The second one is to suggest that the form is influenced by the contact with Èbìrà spoken in Òkenné which is about 28 kilometers away from Àyèré. The $[\mathrm{l}] \rightarrow[\mathrm{r}]$ alternation is common to Èbìrà. Apart from the close distance between Òkenné and Àyèré, some speakers of Èbìrà who are mainly farmers are also settled in Àyèré.

It is also observed that Úwù breaks the cluster of consonants either by the introduction of an epenthetic vowel $[\mathrm{u}]$ or $[\mathrm{i}]$ depending on the roundness or unroundness of the vowels that occur after such clusters, on the one hand, and also the involvement or non-involvement of a labial consonant on the other hand. $[\mathrm{u}]$ is usually inserted whenever the vowel that occurs after the cluster is a round vowel or when the cluster involves a labial consonant otherwise, the vowel [i] is usually inserted. The same condition also determines which of the vowels is inserted when a word ends with a consonant. Consider the illustration below:

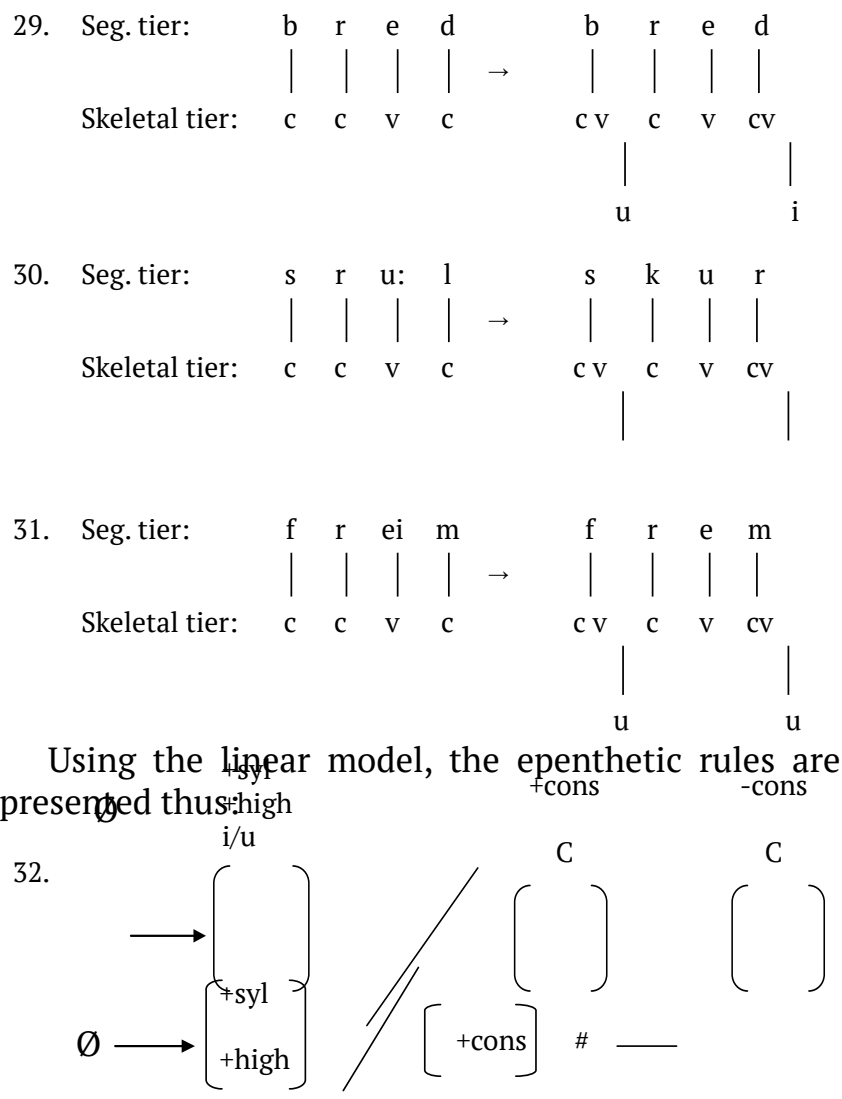

33.

The alternative use of the epenthetic vowels [i] and $[u]$ as seen in the data above is not peculiar to Úwù. Egbokahare (1990) observes in Emai that [u] occurs also as the epenthetic vowel after labial consonants, it also occurs after other consonants if a rounded vowel occurs in an adjacent syllable. [i] occurs as the epenthetic vowel in non-labial environments. Adeniyi (2008) also asserts that the case of Emai as reported by Egbokhare (1990) is also applicable to Edo. Egbokhare (1990) further observes that a similar situation is reported in Yorùbá by Awobuluyi $(1967 ; 1978)$ and Pulleyblank (1988). He notes that Pulleyblank accounts for the phenomenon in Yorùbá in terms of the application of redundancy rules and labial harmony rule. Redundancy rules account for the occurrence of [i] being the underspecified vowel while labial harmony ensures that [i] becomes $[u]$ in the labial context. He stated further that "since consonants can only occur in the onset position, any unsyllabified consonant must be assigned a rhyme. And since there would be no motivation for any particular vowel quality to be present on that rhyme, the unmarked expectation will be for redundancy rules to fill in feature values for such an epenthetic vowel. The illustration below shows 
the pattern of \&penthesis in Æorùbá:

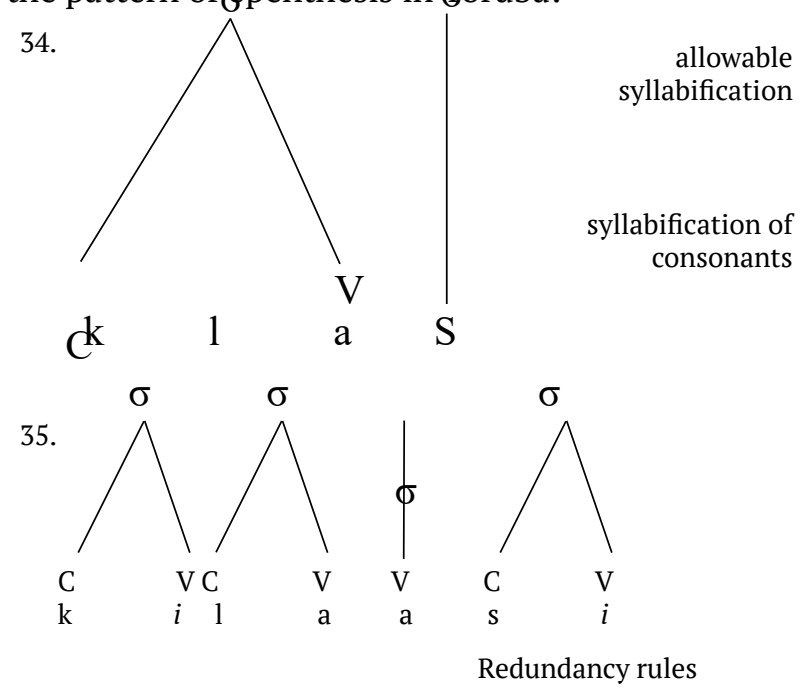

Pulleyblank provided strong motivations for recognizing [i] as supplied by redundancy rules in Yorùbá which is also observed to be true about Úwù. [i] is therefore postulated as the epenthetic vowel in Unuù. The Vowel becomes [u] in a labial environment as a result of the application of labial harmony rule which spreads the labial feature of a labial sound occurring in an adjacent syllable on the inserted vowel [i]. Egbokhare (1990) gives an accurate picture of the insertion process in Emai which fits squarely into Úwù. This is captured by the derivation below:

$$
\begin{aligned}
& \text { 36. } \emptyset \rightarrow[\mathrm{i}] \quad \rightarrow \quad[\mathrm{u}] /[+ \text { labial }] \\
& \text { by insertion by labial harmony }
\end{aligned}
$$

Other salient observations are the cases of vowel lengthening, the High-Low (HL) tone sequence on the lengthened vowels and the low tone on the epenthetic vowel $[\mathrm{i} / \mathrm{u}]$ that ensures that a nativised English word conforms to the open syllable structure of the Úwù language. On this note, Oyebade (2008) reports that Ayo Bamgbose and Kenstowicz (2000, p. 1) had observed a similar case in the Yorùbá language and both claimed that the lengthening was an attempt by the recipient language to stay faithful to the falling intonation pattern of English stressed syllable; since Yorùbá disallows glide tone on short vowels, it adopts the strategy of lengthening to accommodate the gliding pitch of English stress. However, Oyebade takes a look at the lengthening using the optimality theory, and makes a convincing argument about the process in Yorùbá. According to him, vowel lengthening in Yorùbá is motivated by the desire to preserve the prosodic structure of the input syllable from English. He argues this by saying that "stressed syllables in English are mainly bimoraic. In other words, they have a duration that is longer than their unstressed counterparts.
This fact can be asserted more firmly for heavy syllables. Heavy syllables are those ones with long vowel, diphthong or an arresting coda (that is, closed syllable)" (Oyebade 2008, p. 43). He went further to remark that lengthening in Yorùbá words on English providence is motivated by the desire of Yorùbá to preserve the prosodic structure of the syllable(s) of such word(s) as they come from their source. Thus, a monosyllabic word like 'brush' with an arresting coda comes with the prosodic structure:

37.

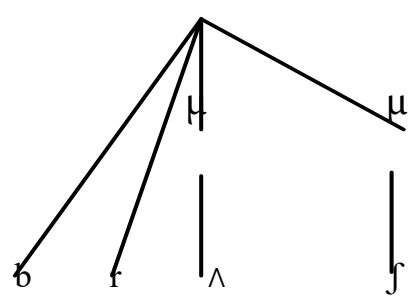

Borrowed into Yorùbá word, the word presents the structure below:

38.
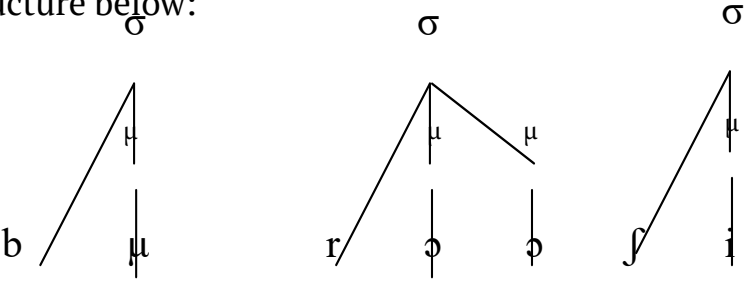

Notice that the structure of the input syllable is preserved subject to the ban, in Yorùbá, of complex onset in a syllable and prohibition of arresting consonant. The same is applicable to all monosyllabic words. Oyebade's argument is affirmed in this paper as the same case is applicable to Úwù.

\section{Conclusion}

This paper has described the manifestation of vowel deletion in Úwù. The paper observes that the process of elision in Úwù occurs in three different grammatical constructions that include:associative morpheme + noun, verb + noun, and pronoun + future tense morpheme. The vowel of the AM is usually deleted whenever the morpheme precedes a vowel-initial noun. In a verb phrase (or verb + noun construction), the vowel of the verb is usually deleted when the verb is a monosyllabic one. In a verb phrase where the verb is a disyllabic or tri-syllabic one, no phonological change occurs unless the contiguous vowels are identical (in which one of the vowel is usually deleted). In a construction involving a pronoun + future tense 
morpheme, the vowel of the pronoun is usually deleted. When a vowel is deleted, autosegmental features like high tone, nasality and roundness usually survive the process and then realign with other neighboring segments. From the foregoing, it could be concluded that in a $\mathrm{V}_{1} \# \mathrm{~V}_{2}$ construction in Úwù, $\mathrm{V}_{1}$ is usually deleted while $V_{2}$ survives the deletion process, which the pattern of vowel deletion is predictable in Úwù.

On the pattern of epenthesis in the language, this research work reveals that only vowels can be inserted into a word, consonant insertion does not exist in the language. Vowel insertion takes place in three positions in Úwù; these are morpheme initial, medial and final. The paper also reveals that [i] is the underlying form of the inserted vowel, and that the vowel usually becomes $[\mathrm{u}]$ in a labial environment. Another salient observation in the paper is the case of vowel lengthening, the HL tone sequence on the lengthened vowels and the low tone on the epenthetic vowel $[\mathrm{i} / \mathrm{u}]$ that ensures that a nativised English word conforms to the open syllable structure of Úwù language. On this note, it is observed that these were motivated by the need to stay faithful to the prosodic structure of the donor language. These various observations imply that the pattern of insertion in Úwù does not differ from findings in earlier research on the manifestation of epenthesis in Benue-Congo languages. Finally, the paper holds that nouns in the language are mainly vowel-initial.

One of the major problems confronting minor languages is that not only are they endangered, quite a number of them are fast going into extinction without any form of documentation (Allison, 2015, p. 7). One of the ways to salvage endangered languages from going into extinction is to document them. It is therefore recommended in this paper that more researches should be carried out on Úwù. Future researchers should look into other aspects of phonology, morphology, syntax, semantics and sociolinguistics. The native speakers of Úwù are also enjoined to produce literature materials on the language. These two steps will make people know about the structure and grammar of Úwù and by implication ensure that the language is documented.

\section{References}

Abiodun, M. A. (2000). Aspects of the phonology Ukaan. Journal of Humanities, 3(2), 77-98.

Abiodun, M. A. (2002). A comparative phonology and morphology of Ukaan dialects of old Akoko division (Unpublished doctoral dissertation). Department of Linguistics and Nigerian Languages, University of Ilorin, Nigeria.

Abiodun, M. A. (2004). A morpho-phonic account of vowel deletion in Yorùbá. Journal of Yorùbá Studies Association of Nigeria, 3(1), 59-71.

Abiodun, M. A. (2007). Phonology. In Y. Ore (Ed.), Basic Linguistics for Nigerian Languages. Ijebu-Ode, Nigeria: Shebiotimo Publications.

Adeniyi, H. R. (2007). A phonology of Edo (Unpublished doctoral dissertation). University of Ibadan, Ibadan, Nigeria.

Adeniyi, H. R. (2008). English loanwords in Edo. Ihafa: Journal of African Studies, 5(3), 57-75.

Adive, R. A. (1989). The verbal piece in Ebira. Dallas, TX: Summer Institute of Linguistics.

Allison, I. O. (2015). Aspects of the phonology of Uwu language in Kogi state (Unpublished master's thesis). Ekiti State University, Ado-Ekiti, Nigeria.

Awobuluyi. O. (1978). Essentials of Yorùbá grammar. Ibadan, Nigeria: Oxford University Press.

Awobuluyi. O. (1996). Vowel epenthesis in Yorùbá. Paper presented at a seminar in the department of Linguistics and Nigerian Languages, University of Ilorin, Nigeria.

Awobuluyi. O. (2013). Ėkó gírámà Èdè Yorùba [Yoruba language grammar]. Ồsogbo, Nigeria: ATMAN Limited.

Bamgbose, A. (1966). A grammar of Yorùbá. In West African Language Monograph Series. Cambrige, UK: Cambridge University Press.

Bamgbose, A. (1967). A short Yorùbá grammar. Ibadan, Nigeria: Hienemann Educational Books Ltd.

Bamgbose, A. (2006). Fonoloji ati giramma Yorùba [Phonology and Yoruba grammar]. Ibadan, Nigeria: University Printing Press.

Egbokhare, F. O. (1990). A phonology of Emai (Unpublished doctoral dissertation). University of Ibadan, Ibadan, Nigeria.

Elugbe, B. O. (1973). Comparative Edoid phonology (Unpublished doctoral dissertation). University of Ibadan, Ibadan, Nigeria.

Elugbe, B. O. (1989). Comparative Edoid: Phonology and lexicon. Port-Harcourt, Nigeria: University of PortHarcourt Press.

Ekpe, M. B. (2012). Aspects of the phonology of Anaang (Unpublished master's thesis). University of Ibadan, Ibadan, NIgeria.

Frajzyngier, Z. (2003). Tone and vowel deletion, insertion, and syllable structure. In R.-J. Anyanwu (Ed.), Stress and Tone. The African Experience: Frankfurt African Studies Bulletin, 15 (pp. 83-98). Frankfurt/Main, Germany: Goethe-University.

Glowacka, D. (2001). Unstressed vowel delition and new consonant clusters in English. Poznan Studies in Contemporary Linguistics, 37, 71-94.

Hall, N. (2006). Cross-linguistic patterns of vowel intrusion. Phonology, 23(3), 387-429.

Ibikunle, A. (2014). Aspects of the phonology of İyịnnọ́ (Unpublished master's thess). University of Ibadan, 


\section{VOWEL DELETION AND INSERTION IN ÚWÙ}

Ibadan, Nigeria.

Kenstowicz, M. (1994). Phonology in generative grammar. Malden, MA: Blackwell Publishers.

Molczanow, J. (2007). Russian vowel reduction and phonological opacity. The Slavonicand East European Review, 85(2), 201-230.

Oyebade, F. O. (1998). A course in phonology. IjebuOde, Nigeria: Shebiotimo Publications.

Oyebade, F. O. (2008). Prosodic structure preservation and English loanwords in Yorùbá: A constraintbased account. Ihafa Journal of African Studies, 5(3),
38-56.

Pulleyblank, D. (1988). Vocalic underspecification in Yorùbá. Linguistic Inquiry, 19, 233-270.

Schiffman, H. F. (1993). Intervocalic - v - deletion in Tamil: Evidence for aspect as a morphological category. Journal of the American Oriental Society, 113(4), 513-528.

Uffmann, C. (2002). A typology of epenthetic vowels in loanwords. Retrieved from http://www. ai.mit.edu/projects/dm/featgeom/uffmannepenthLoanwords.pdf 